DOI: https://doi.org/10.3126/njdrs.v17i0.34951

\title{
Extarcing Trading Locus: Where we are in Indo-Nepal Trade?
}

\author{
Khom Raj Kharel, PhD* and Dhan Raj Chalise** \\ *Associate Professor at Tribhuvan University, Saraswati Multiple Campus \\ ** Assistant Professor of Management, Tribhuvan University \\ Email for correspondence: kharelkhom@yahoo.com and sgreport2dr@gmail.com
}

\begin{abstract}
Nepal and India have had trade relations since time immemorial. Nepal was known as an exporting nation in the ancient times. Before thetrade agreement between Nepal-Britain Treaty in1923, Nepal's trade with India was more than 95 percent. Despite various treaties and agreements between Nepal and India, Nepal's trade with India now accounts for around 65 percent of total trade. Despite the trade and mutual relations between Nepal and India, India has been treating Nepal on the basis of benefits. In different time periods, India has been creating problems in trade and transit, contrary to international norms and trade and transit treaties, under various pretexts. The objective of this paper is to review of Indo-Nepal trade and transit treaties and analyzing the present status.Descritptive and analytical research design is applied and simple statistical tools are used to analyze the growth and direction of foreign trade of Nepal. Linear regression model is applied to measure the total trade with India and total volume of foreign trade of Nepal. This study has found that there has been significant contribution of total trade with India to the total volume of foreign trade of Nepal. The import trade of Nepal with India is extremely high in comparison to export trade and total trade balance and trade balance with India has been increasing with a huge deficit.
\end{abstract}

Key words:Trade treaties, review, present status, direction, and descriptive statistics

\section{Issues of the Study}

Nepal and India are the good trade partner countires. As pointed the reference by economist Kautilya, there was trade relations between Nepal and India in 400 BC. Trade between Nepal and northern India increased during the Golden Age of the Guptas in the early 320s BC. During the Nepal-Tibet War of 1791, the East India Company proposed a seven-point treaty between Nepal and British India for the import and export of goods with a tariff rate of 2.25 percent. In 1816, the Britain signed the Sugauli Peace Treaty to enter Nepal's market. Before the Nepal-Britain Treaty 1923, more than 95 percent of foreign trade of Nepal was with India alone. At that time, Nepal's foreign trade was limited to India and Tibet. The trade route between India and Tibet was through Nepal but Nepal's main trade was with India (Bahadur \& Lama, 1995).

Even before the trade agreement, the British East India Company wanted to have trade relations with Nepal to expand its export trade. In order to expand trade between Nepal and India, emphasis was laid on the development of transport and trade centers in the northern part of India. Before the political upheaval of 1951, Nepal was alienated from the West. Before 1950, Nepal had opened interaction with Tibet and Nepalese currency was in circulation in Tibet. Trade between Nepal and Tibet used to take 
place without any hindrance.

Goods and people could easily move between Nepal and Tibet. After 1951, as Nepal's inclination towards the south increased, activity towards Tibet began to decline. In the first half of the 19th and20th centuries, trade between Nepal and India remained almost the same. Nepal mainly exported food grains, raw jute, wool, cotton, leather, musk, ayurvedic herbs, cardamom, metal utensils, ghee, tobacco, etc. to India. From India mainly agricultural products like wheat, rice, pulses, iron, brass, copper, cotton, salt, livestock etc. were imported. India was not only a trading partner of Nepal but also a good neighbor. Nepal has cultural ties with India. Even today, more than 65 percent of Nepal's foreign trade is with India alone.Trade between Nepal and India is guided by trade and transit treaties. This article is basically focused on review of Indo-Nepal trade and transit treaties and analyzing the present status of trade.

\section{Research Review}

Prior to 1950s, India and Tibet were the major trade partners of Nepal. The signing of Treaty of Peace and Friendship, and Treaty of Trade and Commerce between Nepal and India in July 1950 can be seen as the landmark towards the external trade of Nepal. Treaty of Peace and Friendship 1950 formalized close relations between the two countries. It was agreed to remain the treaty for a period of ten years and continue in force for a further period of ten years unless terminated by either party by giving notice of not less than one year in writing. That Treaty can be seen as a non-reciprocal treaty. The Treaty symbolized a balanced document and served for more than five decades to keep harness between the two countries. It can therefore be seen that the pace of organized and diversified trade, in true terms, began after the signing of the Treaty of Trade in July 1950. Article-I of that Treaty made the provision of full and unrestricted right of commercial transit of all goods and manufactures through the territory and ports of India (Shrestha, 2003).

As per Pant (1994), the treaty was modified and renewed on May 19, 1961 and August, 1971 respectively. The treaty incorporated provisions regarding transit facilities extended by India for Nepal's trade with a third country, as well as on cooperation to control unauthorized trade. The treaty provided freedom of transit through the territories of theeither country without making any distinction of flag of vessels, the place of origin, entry, exits etc.

Duty free access to Nepalese imports on a non-reciprocal basis was first given in 1971 but with a Nepalese/Indian material content requirement of 90 percent. That was gradually reduced when the Trade Treaty was periodically renewed in 1978; it was brought down to 50 percent of Nepalese/ Indian material content and Nepalese labor content. In 1978, instead of a single Treaty, three different agreements were signed. Those treaties were modified significantly in 1991, after the advent of democratic government in Nepal. India signed two treaties on trade and transit with Nepal in 1991. Indo-Nepal Treaty of Trade 1991 made the provisions of extending substantial concessions (Shreshtha, 2003).

The growth of trade basically depends upon the conditions that create within the national boundary in respect of measures related to investment promotion and improvement in governance. This would require addressing the issues of frequent politically motivated strikes, lock-out, obstruction of transport, industrial relations and labor issues in industries and the rent seeking behavior at political and bureaucratic level of the government. The experience has shown that those issues seem to be more 
serious during the political transition and moreover there are reports of extortion, harassment, forced donation, and unofficial payment appearing in the media almost every day. These kinds of situation need correction in order to provide assurances to the domestic and the foreign investors that encourage them to make productive investment in Nepal. There is need of revisiting the composition of export basket and the identification of niche products and markets that will help in creating equity to the various communities and groups within the country.

Trade development agenda should focus on inclusiveness that encompasses to various ethnic groups and geographical region as has been the jargon of building a new democratic republic Nepal. It has to be borne in mind that the improvement and sustenance in export trade can take place with the development of potential products, its quality and quantity and the competitive price to offer. It demands for increasing productive capacity of the economy and improvement in the investment climate in the country. It is essence that there is need of introducing necessary reform measures across all sectors of Nepalese economy to reap benefits from the market access opportunities (Ojha, 2011).

As remarked by Silwal (2011), the new provision in the treaty to institutionalize is the IGC. The provisions of the treaty were very favorable to Nepalese industries and exporters as the treaty provides duty free market access as well as other supplementary facilities to Nepalese products in the huge and fast growing Indian market. However, attempts to grasp the benefits of those provisions of new treaty are awaited from the part of our business community.

Nepal basicallyexports primary and unprocessed or semi-processed commodities with lower value products to India, such asthreads, zinc sheet, polyester yarn, vegetables ghee, etc. In contrast, Nepal basically imports finishedproducts with high value products such as petroleum products, vehicles and spare parts, machinery parts, chemicals,Medicines, electricity equipments, cement, etc. from India. The volume of trade between Nepal and India is increasing rapidly. Particularly, from the beginning of $21^{\text {st }}$ century, Nepalese export to and import from India soared. Nepal's almost two-third share of trade occurs with India only. In this way, in terms of trade, Nepal is over concentrated and over dependent with India in the latest decade. Nepal's trade both exports and imports, has been heavily concentrated on a single country- India-and a few primary products. Political and economic risks associated with such a heavy dependence have been realized by Nepal's policy makers since long. To overcome risks and vulnerability associated with such dependence and to high growth, exportdiversification was considered as the primary goals of Nepal's development strategy (Dhakal, 2011).

Trade and Transit Treaties, held between Nepal and India, can be seen as the outcomes of progress and understanding towards improving trade relationship between the two countries. It can also be seen as the reform initiatives of the both countries as per demand of the Socio-economic and Geo-political framework. Those treaties had been quite comprehensive concentrating on the issues of hazardous cargo, insurance, quantum of primary commodities and rules of origin. The rules of origin norms enabling preferential treatment of the Nepalese manufactured goods for entry into the Indian market had gradually been relaxed to improve coverage of eligible products. The number of primary commodities eligible to enter into both the countries free of restrictions had been increased. Similarly, the number of transit points to facilitate Nepal's trade with India and, also Nepal's trade with third countries through Indian territory had been expanded.

Realizing the significance of the bilateral treaty and its impact on the foreign trade, it had 
been remarked that the Indo-Nepal bilateral economic cooperation treaties had led to significant policy inferences for future economic cooperation in the South Asian Region (SAR). It was due to the fact that India has emerged as a major trade partner of Nepal as both exports and imports in value terms have been quite high in comparison with Nepal's major trade partners. The possible reason for that tendency could be the freer trade regime that had existed between India and Nepal. Taking into account the fact that study had made an attempt to analyze the provisions made in the trade and transit treaties and the major impact of those on the structure and trend of Indo-Nepal trade. There are plenty of studies devoted to examine the Indo-Nepal trade and transit treaties. But there is not specific study of the review of Indo-Nepal trade tand transit treaties comprehensively. This study has been conducted to review the Indo-Nepal trade and transit treaties and analyzing the present status of trade of Nepal with India.

\section{Research Problem and Objectives}

India is the biggest trade partner of Nepal. For systemize the trade between Nepal and India, there have been conducted trade and transit treaties. The treaties and agreements made by Nepal, especially with India, are made keeping in view the personal and party interests rather than the national interest. At different times, the Government of Nepal has been tacitly agreeing with the Indian side of the border with Nepal. There have been many incidents where the Nepalese government has remained silent even when Indian security personnel openly enter Nepal with weapons. The fact that Nepalese have remained silent even when the neighboring country China has raised the issue of blockade imposed by the Indian side in the past, shows the nature of our diplomatic relations. Apart from these, India has been creating problems in Nepal's trade and transportation at different times due to various reasons such as the role of leaders of Nepal's political parties, dependent behavior and consumption structure of Nepalese, political instability, open borders and uncontrolled border areas, marital and cultural relations. The study reports have pointed out that there should appropriate trade and transit agreements between Nepal and India. The basic objective of this study is to review the Indo-Nepal trade and transit treaties and analyze the present status of Nepal with India.

\section{Data and Method}

This study is the descriptive and analytical in nature. So the descriptive and analytical research design has been applied. In case of descriptive research design, different tables, diagram and examples has been presented as necessary. Similarly, simple linear regression model has been applied to measure the linkages between total volume of trade deficit and total trade with India. The essential data for this study were gathered from the publications. Different Indo-Nepal trade and transit treaties, data published by various government and non-government organizations have been used to analyze the situation. Economic Survey published by Ministry of Finance, data published by Trade Promotion Center and Statistical Year Book and other reports published by Central Bureau of Statistics. Apart from this, reports published by other related sector were also applied. To analyze the relationship between total volume of trade and total trade with India simplelinear regression model has been applied.

\section{Results and Discussions: Review of Indo-Nepal Trade Treaties and Transit}

The continuation of trade between Nepal and India continued without a treaty until the 1923 agreement with British India. Prior to the treaty, trade with India alone was more than 95 percent. At 
that time, the British India Company was willing to establish trade relations with Nepal to increase exports to Nepal. Before the trade agreement between Nepal and British India in 1923, more than 95 percent of trade was with India alone. Article 4 of the trade treaty of 1923 envisioned that only the ports of British India should be used for the promotion of trade between Nepal and the British. Nepal was banned from importing goods from overseas countries. Nepal was forced to buy only goods made in Britain.

Immediately after the independence of India, a peace and friendship treaty was signed between Nepal and India in 1950. On July 31, 1950, a trade and commerce treaty was signed between Nepal and India in Kathmandu for a period of 10 years without any formal written notice. The peace and friendship treaty formalized the rapprochement between the two countries. The treaty is seen as a non-reciprocal treaty. Provision of Article 1 of the Trade Treaty of 1950 has made provision for Nepal to have full and undoubted trade transit of all goods and products from any part of India and any port. The treaty was renewed in 1961 and 1971, respectively. The treaty undoubtedly provides for the expansion of the provision of transit facilities for Nepal to third countries and for assistance in controlling unauthorized trade. The treaty provides for freedom of movement from inside or outside the country by placing a different flag in a vehicle.

In the 1971 treaty, the Government of India agreed to allow all primary products produced in Nepal from Nepaleseor Indian goods to enter the Indian market without basic tariff rates and consequential barriers. The Trade Agreement of 1971 provided a lump sum refund to Nepal for the amount of tariffs and other customs duties levied on goods exported from India to Nepal.In 1978, a new treaty was signed between the two countries with broad objectives. The treaty consisted of three agreements: a trade treaty, a transit treaty and an agreement to help control illegal trade. The treaty provided for the exemption of general customs and quantitative restraint on 12 primary commodities. Similarly, the transit treaty has provided the facility to keep the goods brought by Nepal in ships at Calcutta and Haldia ports of India for free for 7 days. Nepal has been given the opportunity to trade with third countries through Bangladesh.

India had opened 21 ports for trade between Nepal and India. The 1978 treaty was renewed in 1983 and 1989 with some modifications for the next five years. After the expiration of the trade and transit treaties in 1989, the trade and transit treaties were broken for about 15 months. Of the 21 checkpoints, only two were opened by India. Other ports India imposed trade blockade on Nepal. Shortly after the success of the multi-party democratic movement, trade and transit treaties were renewed from time to time in 1991, 1996, 2002, 2007, 2009 and beyond. After 1991, Nepal entered the fray and accordingly initiatives were taken for trade and transit treaties and agreements between Nepal and India.

The Trade Treaty, which was renewed in 1996, brought about significant changes in bilateral trade. That treaty also introduced a new system in the transit treaty. The role of the trade agreement between Nepal and India in 1996 is considered very important. In particular, the treaty is considered a starting point for export trade and industrial development in Nepal's economy. The treaty has provided a liberal framework for Nepal-India trade relations. In that treaty, there was the provision of government of India could allow all products manufactured in Nepal to be exported to the Indian market on the basis of customs duty and quantitative constraints on the basis of source/start certificate. Government 
of India would open Phulbari port for transit to Bangladesh, no delay the goods exported by Nepal with source, increase the number of air seats per week and both government agree on an open sky policy.

The Government of Nepal has made changes in various aspects such as reforming its foreign investment policy, company law and technology transfer act. Apart from these, the treaty had created a conductive environment for trade and investment between Nepal and India. From that treaty, Nepal had many opportunities but could not make proper use of them. The treaty was re-signed in 1999 .

In 1999, a transit agreement was signed between Nepal and India. The transit treaty is very important for landlocked countries like Nepal. Social, economic and development needs depend on import and export trade. The provisions of the treaty were to be renewed automatically for each of the next seven years. It was viewed from the positive side of a treaty. In the past, the treaty was viewed with a view to reducing administrative procedures. The previous Nepal-India Transit Treaty provided for 15 ports between Nepal and Calcutta for transit between Nepal and India. In addition, 22 checkpoints were set up for entry and exit for Nepal-India mutual trade and transit.Due to increasing competition due to Nepal's exports, the problem of obstruction has been increasing due to pressure from Indian industrialists. In 2002, the 1996 treaty was amended with some additions. Provisions such as quotas on exports of some items as well as additional tariffs on exports were added. As a result, problems began to arise in Nepal-India trade and transit. In 2007, the Nepal-India Trade Agreement was renewed. The renewed treaty did not address some of the current major issues, such as the non-tariff rate. Cooperation and consensus were also expected in some additional areas, but did not improve as expected.

In 2009, the Nepal-India Trade Agreement was renewed for a period of seven years to address the additional tariff and non-tariff barriers related to Nepal. However, it is doubtful that the change will improve Nepal's export trade to India. Nepal introduced five additional tariffs, emphasizing agricultural development charges on Indian products. In 2009, an agreement was signed between the two countries to control unauthorized trade between Nepal and India. The agreement was renewed for seven years with effect from 2009. The main purpose of the treaty was to control illegal trade between the two countries.

Similarly, India has emphasized the need for bilateral economic cooperation. In order to make trade more import-oriented and more mutually beneficial and mutually beneficial, the two countries have agreed to expand trade and investment agreements in Nepal. While India has shown interest in coordinating non-tariff barriers while exporting goods to India, India has shown interest in trade promotion.

Even in recent treaty agreements, India seems to prioritize its favorable agenda and impose it on Nepal by force. India ignores the impact of its policies and regulations on its neighbors, but has a vulture attitude towards its policies and regulations. The question of what affect the newly introduced Goods and Services Tax has on the economy of a neighboring country like Nepal has not been touched upon. But on the issue of Nepal, it has been looking at the constitution drafted by the Constituent Assembly. Despite various trade and transit treaties and agreements signed between Nepal and India at various times, India has been a good neighbor to Nepal and has been ignoring the unimpeded transit facilities of a landlocked country as per the 1965 provisions of the United Nations. On the one hand, India's attitude towards Nepal seems to be hepatic in nature, while on the other hand, the indiscretion of the Nepalesegovernment and Nepaleseleaders has become a matter of serious concern for Nepal. 


\section{Present Statusof Foreign Trade of Nepal}

The trend of total volume of foreign trade of Nepal hasbeen increasing during the study period. As well total trade with India has also been increasing in almost years. The import trade from India is extremely high in comparison to export to India from Nepal. The total trade deficit and trade deficit with India is also expanding every years.

Table 1. Trade Balance of Nepalwith India from 2000/01-2019/20 (Rs. in Ten Million)

\begin{tabular}{lllllll}
\hline Year & $\begin{array}{l}\text { Total Volume } \\
\text { of Trade }\end{array}$ & $\begin{array}{l}\text { Total Trade } \\
\text { with India }\end{array}$ & $\begin{array}{l}\text { Import } \\
\text { From India }\end{array}$ & $\begin{array}{l}\text { Export to } \\
\text { India }\end{array}$ & $\begin{array}{l}\text { Trade Balance } \\
\text { with India }\end{array}$ & $\begin{array}{l}\text { Trade } \\
\text { Balance }\end{array}$ \\
$2000 / 01$ & 17134.13 & 7124.12 & 4521.10 & 2603.02 & -1918.08 & -6003.31 \\
$2001 / 02$ & 15433.38 & 8457.83 & 5662.21 & 2795.62 & -2866.59 & -6044.42 \\
$2002 / 03$ & 17428.27 & 9735.42 & 7092.42 & 2643.00 & -4449.42 & -7442.15 \\
$2003 / 04$ & 19018.78 & 10951.78 & 7873.95 & 3077.71 & -4796.24 & -8236.64 \\
$2004 / 05$ & 20817.93 & 12759.24 & 8867.55 & 3891.69 & -4975.86 & -9076.79 \\
$2005 / 06$ & 23401.44 & 14785.78 & 10714.31 & 4071.47 & -6642.84 & -11354.62 \\
$2006 / 07$ & 25407.77 & 15760.11 & 11587.23 & 4172.88 & -7414.35 & -13531.15 \\
$2007 / 08$ & 28120.42 & 18093.22 & 14237.65 & 3855.57 & -10382.08 & -16267.12 \\
$2008 / 09$ & 35216.71 & 20344.35 & 16243.76 & 4100.59 & -12143.17 & -21677.21 \\
$2009 / 10$ & 43515.92 & 25710.80 & 21711.43 & 3999.37 & -17712.06 & -31351.12 \\
$2010 / 11$ & 46051.40 & 30528.60 & 26192.50 & 4336.00 & -21856.50 & -33183.70 \\
$2011 / 12$ & 53592.90 & 34900.60 & 29939.00 & 4961.60 & -24977.30 & -38740.70 \\
$2012 / 13$ & 63365.80 & 41803.10 & 36703.10 & 5100.00 & -31603.10 & -47982.30 \\
$2013 / 14$ & 80635.70 & 53756.10 & 47794.70 & 5961.50 & -41833.30 & -62237.50 \\
$2014 / 15$ & 86000.30 & 54752.10 & 49165.60 & 5586.50 & -43579.10 & -68936.5 \\
$2015 / 16$ & 84371.60 & 51670.60 & 47721.30 & 3949.40 & -43771.90 & -70348.20 \\
$2016 / 17$ & 106316.3 & 67511.90 & 63367.00 & 4144.90 & -59222.00 & -91706.40 \\
$2017 / 18$ & 132646.3 & 86082.10 & 81410.20 & 4672.00 & -76738.20 & -116374.30 \\
$2018 / 19$ & 151564.50 & 98064.10 & 91790.90 & 6273.20 & -85517.80 & -132142.60 \\
\hline
\end{tabular}

(Economic Surveys, 2000/01-2019/20)

Table 1shows that total volume of foreign trade of Nepal and total trade with India, import trade from India, export trade to Inida, trade balance with India and total trade balalnce of Nepal from $2000 / 01$ to $2018 / 19$. The total volume of foreign trade, trade with India has been increasing and mostly import trade from India and export trade to India has also been increasing during the study period. The data shows that trade deficit with India and total trade deficit of Nepal has been widening each year and becoming a serious matter of Nepal. 


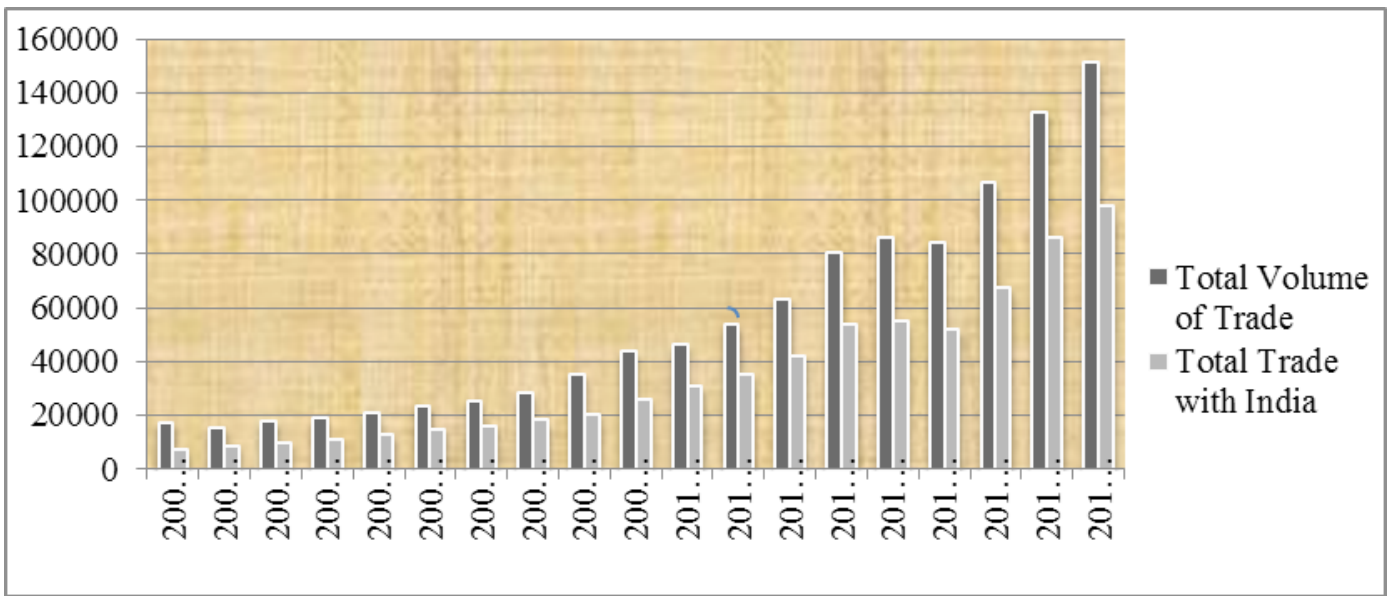

(Economic Surveys, 2000/01-2019/20)

Figure 1. Total Volume of Trade and Total Trade with India from 2000/01-2018/19

Figure-1 depicts that the total volume of foreign trade of Nepal and total trade with India. Trade with India holds a significant ratio of foreign trade of Nepal. Analyzing nearly two decades of total volume of trade of Nepal and total trade with India, Nepal's foreign trade seems to be pro-India. Trade with India is import oriented whereas trade with represents around 65 percent. Thus, on the one hand, due to Nepal's growing trade deficit with India, there is a gradual shortage of Indian currency, while on the other hand, due to the declining number of Nepaleseworkers in the Indian market, there is a short of Indian currency.

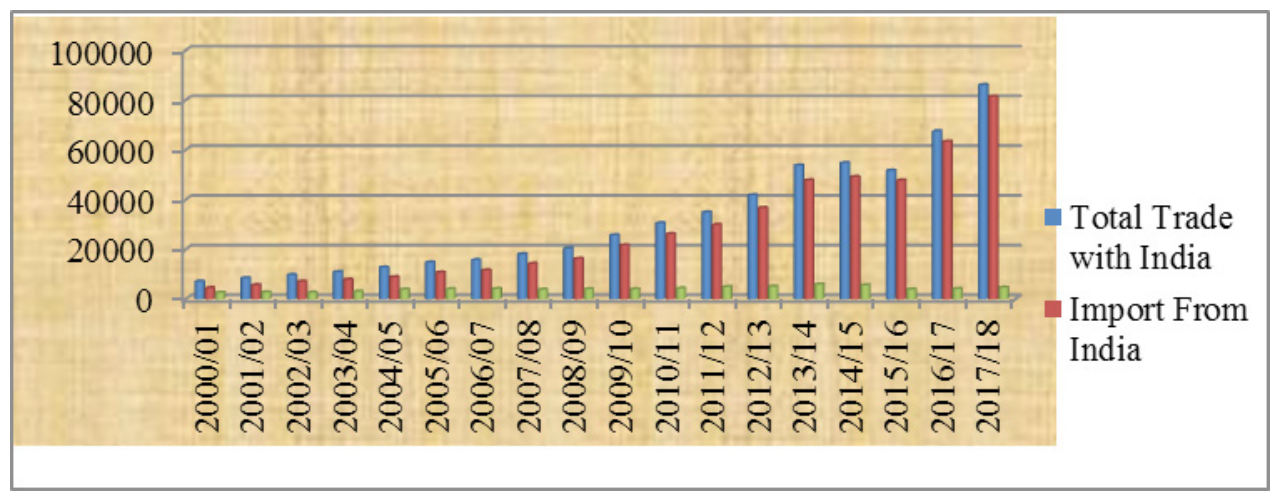

Figure 2. Total Trade with India, Import Trade from India \& Export Trade to Nepal

Figure-2 indicates that Nepal's total trade with India, import trade from India and export trade to India. Import trade from India holds more than 80 percent whereas export trade to India is less than 20 percent. In fact, both Nepal and India are important trading partners. As Nepal is a landlocked country, transit facilities from neighboring countries are a right of Nepal as per the provisions of the United Nations. 

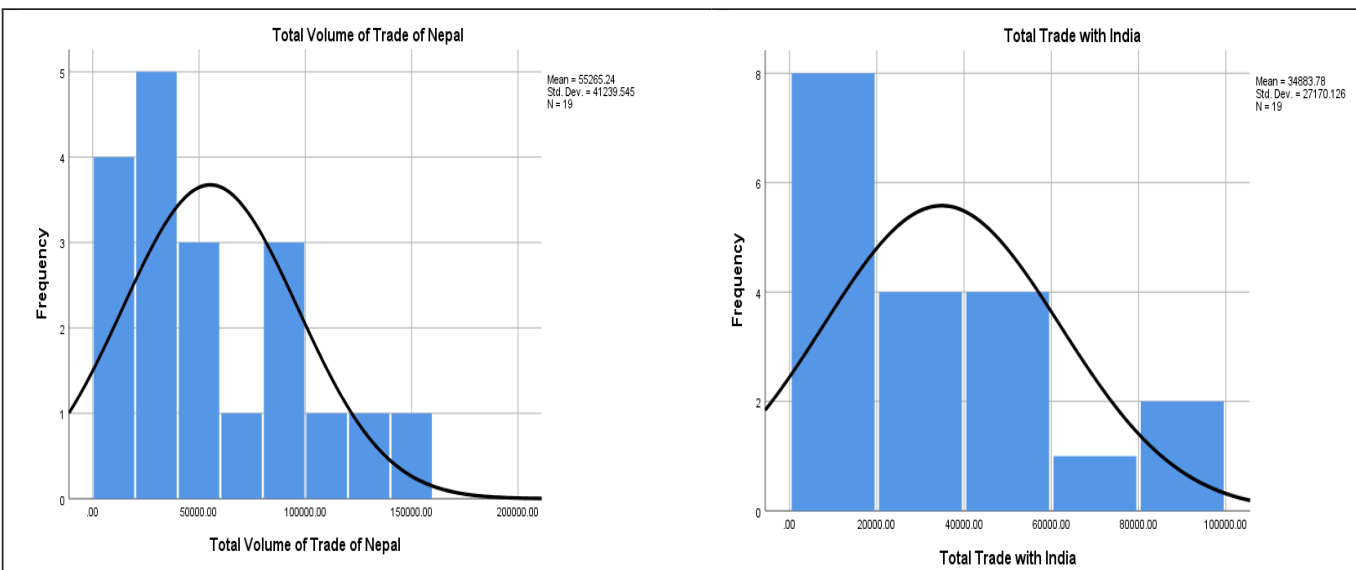

(Economic Surveys, 2000/01-2019/20)

Figure 3. Histogram of Total Volume of Trade and Total Trade with India
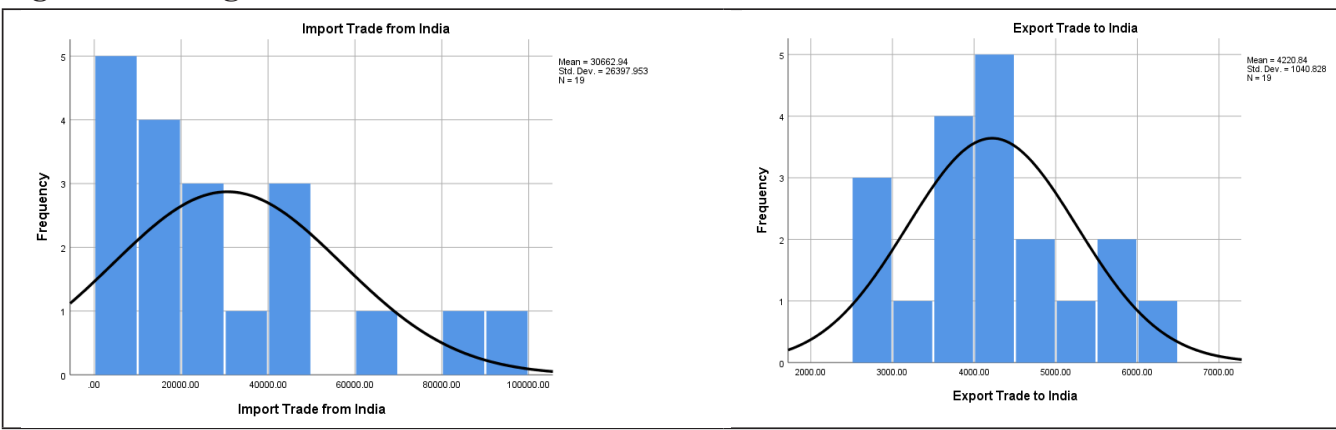

(Economic Surveys, 2000/01-2019/20)

\section{Figure 4. Histogram of Import Trade from India and Export Trade to India}

As shown in the Table-2, $R$ value of 0.999 indicates the strong positive relationship between total volume of foreign trade and total trade with India where $(\mathrm{p}<0.05)$. Similarly, $R$-square value of $0.997 \mathrm{states}$ that 99.70 percent change in total volume of foreign trade of Nepal due to independent variable. Likewise, Standard error of the estimate of 0.323 indicates the variability of the observed value of trade deficit from regression line is 0.018 units. The result shows that there is a significant impact of total trade with India on total volume of foreign trade of Nepal. It signifies that a change in total trade with India indicates that total trade with India is a significant predictor of total volume of foreign trade of Nepal (Table-2). 
Table 2. Regression between Total Volume of Trade and Total Trade with India

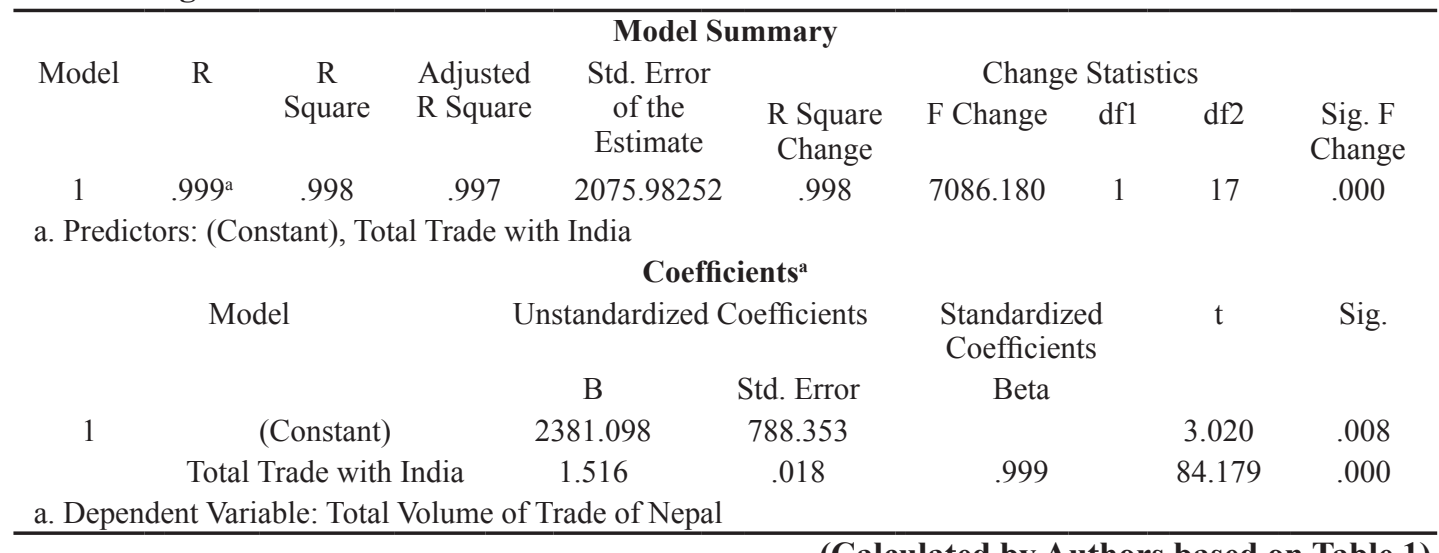

(Calculated by Authors based on Table 1)

When Nepal's economy is strong, India will have a positive impact on security, employment, reciprocity, cultural, social, economic, trade, political, religious, etc. India should treat Nepal from the same point of view.

\section{Direction of Foreign Trade of Nepal}

Direction of foreign trade refers to the trade among Nepal's trading partners. From the earliest time down to the present, Nepal's biggest trade partner has been remained India. Under the efforts to diversify the country-wise foreign trade of the country, though the percentage of trade with India has heavily shrunken down from over 90 percent in early period. India is as yet the biggest trade partner in the total foreign trade of the country. The share of trade with any other individual country is not comparable to that with India. Direction of foreign trade of Nepal is shown in the following Table-3.

Table 3. Direction of Foreign Trade in Nepal from 2012/13 to 2018/19(Rs. in Ten Million)

\begin{tabular}{lcccc}
\hline Fiscal Year & Total Trade (Rs.) & India (\%) & China (\%) & Other Countries (\%) \\
$2012 / 13$ & 63365.8 & $41803.1(66.0 \%)$ & $6453.7(10.2 \%)$ & $15108.9(23.8 \%)$ \\
$2013 / 14$ & 80635.7 & $53756.1(66.7 \%$ & $7615.9(9.4 \%)$ & $19263.7(23.9 \%)$ \\
$2014 / 15$ & 86000.3 & $54752.1(63.7 \%)$ & $10239.6(11.9 \%)$ & $21008.7(24.4 \%)$ \\
$2015 / 16$ & 84371.6 & $51670.6(61.2 \%)$ & $11737.6(13.9 \%)$ & $20963.4(24.8 \%)$ \\
$2016 / 17$ & 106316.2 & $67511.9(63.5 \%)$ & $12894.7(12.3 \%)$ & $25909.7(24.4 \%)$ \\
$2017 / 18$ & 132446.0 & $85641.9(64.9 \%)$ & $16251.6(12.3 \%)$ & $30552.5(23.1 \%$ \\
$2018 / 19$ & 151564.5 & $98064.1(64.7 \%)$ & $20763.7(13.7 \%)$ & $32736.6(21.6 \%)$ \\
\hline
\end{tabular}

(Economic Survey, 2019/20)

In the beginning of foreign trade, more than 95 percent foreign trade was with India only. The foreign trade of Nepal with India was gradually decreasing due to trade diversification of Nepal. Table 3and Figure 5 show that 66 percent total trade of Nepal was only with India, 10.20 percent with China and 23.80 percent with other countries in 2012/13. Similarly, the trade between Nepal and India was 64.70 percent, 13.70 percent with China and 21.60 percent with other countries in the year 2018/19. 


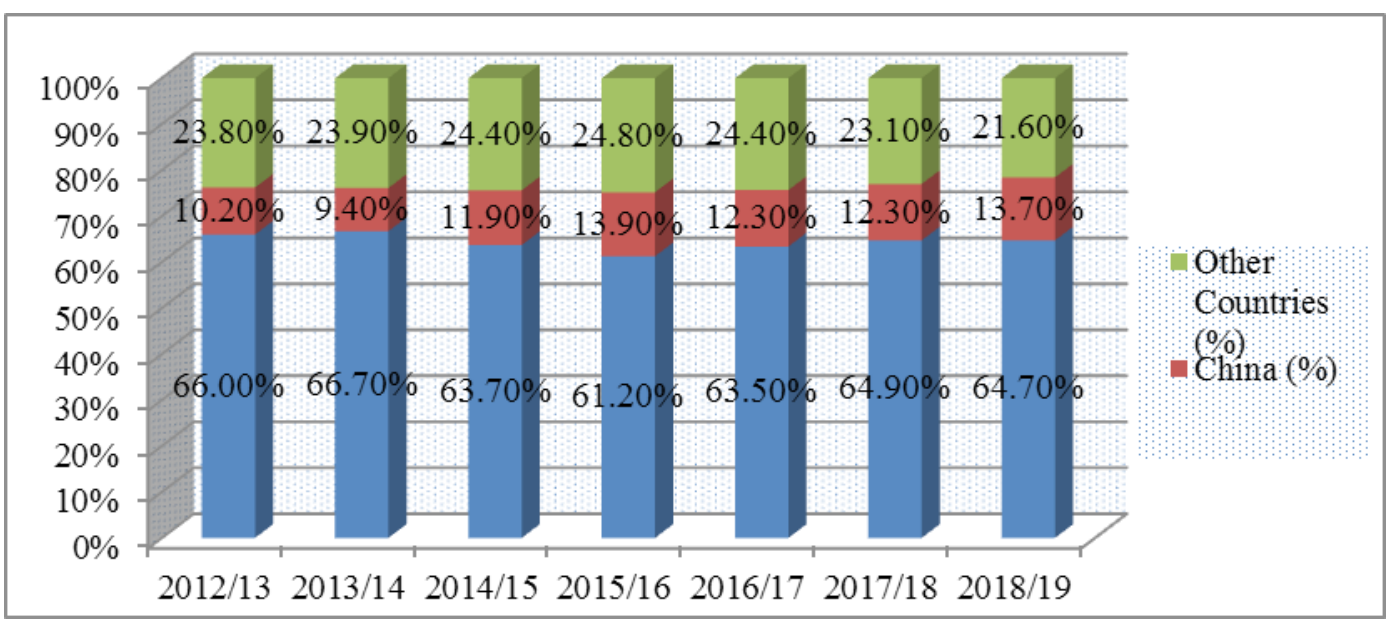

\section{Figure 5. Direction of Foreign Trade}

(Economic Surveys, 2012/13-2018/19)

The scenery of foreign trade of Nepal shows that Nepalese market is dominated by Indian products. Nepal has also not diversified the foreign trade according to commodity wide. Nepal only exports limited goods such as primary goods.

\section{Conclusion}

India's largest trading partner is India. Trade with India has been entrenched in the Nepalese market since ancient times. Before the formal trade agreement between Nepal and India, more than 95 percent of Nepal's foreign trade seems to have been with India alone. Looking at the statistics of the last 18 years, it is clear that India has 65 percent foreign trade with Nepal. Despite such a large amount of trade with India, there have been problems in Nepal. As Nepal's foreign trade structure is India-oriented, India's attitude towards Nepal is not balanced despite being close neighbors. Even though Nepalese people have a positive attitude towards India, the Indian government and Indians have been showing a hepatic attitude towards Nepal and Nepalese. Nepal should have equal relations with both the neighboring countries. Experience so far has shown that the class character of most Nepalese leaders is pro-India. It is found that people look to India for the most common issues and go to great lengths to seek India's blessings. Nowadays, Nepal's political parties should have equal relations with both the neighboring countries. Trade should be done on the basis of mutual benefit. For India and China to be good neighbors of Nepal, so Nepal should treat equally with these countries.

\section{References}

Appleyard, D. R. \& Field, A. J. (1998). International trade (3rd ed.). New York: .The McGraw- Hill Companies, Inc.

Bahadur, K. \& Lama, M. P. (1995). New perspectives on India-Nepal relations. New Dedlhi:.HarAnanda Publications.

Brander, J. \& Spencer, B. (1985). Export subsidies and international market share rivalry. Journal of International Economics, 18(1-2), 83-100.

Nepalese Journal of Development and Rural Studies, Volume 17 
Dahal, M. K. \& Aryal, S. (2003). Improving Nepal-India economic relations: A study of the impact of foreign direct investment (FDI) and transfer of technology in Nepal. Kathmandu: Institute for Integrated Development Studies.

Dhakal, K. P. (2011). How to address critically widening Nepalese trade deficit with India. Kathmandu: MOICS.

Dharamdasani, M. D. (2000). India-Nepal partnership and South Asian resurgence. New Delhi: Kanishka Publishers.

Ministry of Commerce and Supplies (2012). Trade policy review by Nepal. Kathmandu: Government of Nepal.

Government of Nepal (2010). Various Indo-Nepal trade and transits treaties (1950, 1961, 1971, 1991, 1996, 1999, 2002 and 2009). Government of Nepal \& India.

Karmacharya, B. (2006). Price competitiveness and productivity: Nepal trade\& competitiveness study. Kathmandu: World Bank.

Ministry of Commerce and Supplies (1992). Trade policy of Nepal -1992. Kathmandu: Government of Nepal.

Ministry of Finance (2000/01-2019/20). Various series of economic survey 2000/01-2019/20. Kathmandu: Government of Nepal.

National Planning Commission (2007). Eleventh three year plan 2007-2010. Kathmandu: Government of Nepal.

National Planning Commission (2010). Twevelth three year plan 2010-2013. Kathmandu: Government of Nepal.

Ojha, P. (2011). Why revise the Nepal-India treaty of trade? Kathmandu: Ministry of Industry, Commerce and Supplies.

Prasad, U. S. (2007). Nepal's regional and bi-lateral trade agreements: Performance and prospects. Ministry of Industry, Commerce and Supplies, Government of Nepal (Enhancing Nepal's TradeRelated Capacity (ENTReC)

Rodrik, D. (1992). The limits of trade policy reform in developing countries. Journal of Economic Perspectives, 6(1), 87-105.

Silwal, S. P. (2011). Major features of newly signed treaty of trade between Nepal and India. Kathmandu: Ministry of Commerce and Supplies, Government of Nepal. 